\title{
SONIC LAYER DEPTH VARIATION ANALYSIS UTILIZING BIDE (BANDA ITF DYNAMIC EXPERIMENT) ARGO FLOAT IN SITU OBSERVATION FOR UNDERSEA WARFARE TACTICAL ENVIRONMENT SUPPORT
}

\author{
D Armansyah ${ }^{1}$, N B Sukoco ${ }^{1}$, W S Pranowo ${ }^{1,2}$ \\ ${ }^{1}$ Department of Hydrography Engineering, Indonesian Naval Postgraduate School (STTAL), \\ Jl. Pantai Kuta V No. 01, Ancol Timur, Jakarta, 14430, Indonesia \\ ${ }^{2}$ Marine Research Centre, Indonesian Ministry of Marine Affairs and Fisheries, \\ Jl. Pasir Putih II, Ancol Timur, Jakarta, 14430, Indonesia
}

\begin{abstract}
Sonic Layer Depth is the vertical distance from surface to the depth where the speed of sound reach it's local maximum. Global Navy as well as Indonesan Navy operates in this kind of layers on a daily basis, wether it be in an anti submarine warfare operation through its ships and aircrafts or in an anti-surface warfare operation waged by its submarines. For the navy, the importance of knowing the exact value of the SLD is because it determines the minimum cut off frequency and sound wave propagation above which sound tends to be trapped and below which a shadow zone exist. This has a direct impact on where the navy operates its sensors and places its platforms in the water column. The best way to estimate SLD is by performing own measurement on the ocean using instrument such as expendable bathytermographs, which can be relatively expensive and time consuming for an operational navy ships, furthermore such measurement may be impractical in the case of mission planning or emergencies. Dedicated oceanography survey for the purpose of science and defense is relatively scarce due to prioritization concerning to the budget available resulting lack of time series in situ CTD observation which cover full annual cycle variation in Indonesia waters. Banda Indonesia Through Flow Dynamic Experiment (BIDE) is multi institution and bilateral oceanography experiment led by Indonesian scientist which utilizes argo float to perform in situ CTD measurement in Banda Sea to get an adequate time series data that cover full annual cycle variation. The dataset is publicly available so defense community as well may utilize the data for defense interest such as sonic layer depth variation analysis in Banda Sea.
\end{abstract}

Keyword : sonic layer depth, BIDE, argo float, undersea warfare, tactical environment.

\section{INTRODUCTION.}

Sonic Layer Depth (SLD) is the vertical distance from the sea surface to the depth where the speed of sound underwater reachs it's maximum value. The maximum value of sound speed occurs at certain depth due to under a condition when temperature and salinity in a layer is constant, the value of sound speed will increases with pressure/depth until generally temperature, and therefore sound speed decreases. SLD is an important phenomenon because it characterizes the capability or potential of the upper ocean or surface layer to trap acoustic energy in a surface duct. Nevertheless, SLD is not commonly known and researched parameter if compared to another parameter called Mixed Layer Depth (MLD). MLD is the thickness of a ocean surface layer that has almost constant value of temperature, salinity and density, therefore by definition is different with SLD because MLD characterizes how the mixing of upper ocean layer. SLD and MLD are frequently coincide due to the condition that sound speed 
increases with depth down to the MLD, where generally the temperature declines resulting in a local maximum sound speed. Previous reasearchs shown that SLD and MLD are not always the same because sound speed is substantially more dependent to temperature than to salinity compared to density. However scientists and practicioners oceanographers often used MLD as a proxy or substitute of SLD for scientific or operational activities (Helber, et al., 2008).

Estimating the SLD variability is important for understanding the acoustic properties of the upper ocean that influence operational activities such as navy operations related to hiding and detecting marine underwater vessels (Urick, 1983). Navy around the world has a vested interest in knowing exactly where the MLD and SLD especially are located. Global Navy as well as Indonesan Navy operates in both layers on a daily basis, wether it be in an anti submarine warfare operation through its ships and aircrafts or in an anti-surface warfare operation waged by its submarines (Rizanny, 2017). For the navy, the importance of knowing the exact value of the SLD is because it determines the minimum cut off frequency and sound wave propagation above which sound tends to be trapped and below which a shadow zone exist. This has a direct impact on where the navy operates its sensors and places its platforms in the water column (Villareal, 2014).

One of the classical problem facing oceanographers is the scarcity of in situ observations to be used in estimating the temperature and salinity structure of the ocean. Traditionally, they rely on climatologies or collective average derived from all available historical data (Teague, et al., 1990). The other alternative is performing own measurement on the ocean using instrument such as expendable bathytermographs, which can be relatively expensive and time consuming for an operational navy ships, furthermore such measurement may be impractical in the case of mission planning or emergencies (Fox, et al., 2001).

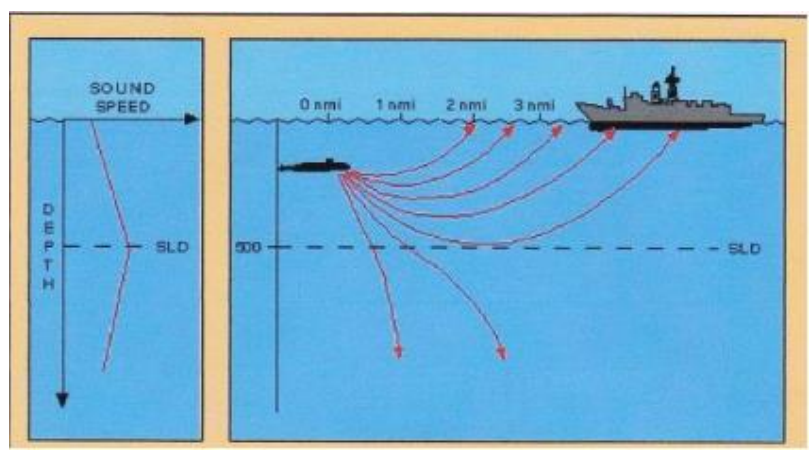

Fig. 1. An example of SLD

(Guest, 2014)

Scarcity of in situ physical oceanography measurement is also a big problem faced by oceanography community in Indonesia especially in the Indonesian Navy. Indonesian Navy Hydrography and Oceanography Centre (Pushidrosal) is the institue responsible for the planning and execution of hydrography and oceanography survey for the public civil and military interests. However, historically at present and possibly in the near future, oceanography survey is remain to be only small part of Pushidrosal operations since there is bigger national maritime strategic development program that must be supported because Pushidrosal is one of the stakeholders who is responsible for providing updated nautical chart for the Indonesia maritime transportation. Nevertheless, Pushidrosal keeps maintaining relations with other national oceanography institution not only for the interest of Indonesian Navy but also for the advancement of national oceanography society and its further contribution for national maritime sector. One of the most recent ocenaography society national collaboration is Banda Indonesian-Throughflow Dynamic Experiment 2017-2018 which is led by scientist from Institut Pertanian Bogor (IPB) and supported by Ristekdikti, LEGOS (France) and IFREMER (France). This experiment is not only introducing Argo float as an advance data collection 
technology but also with this experiment time series measurement data in Banda Sea will be established for full annual cycle which is a huge progress for Indonesia oceanography (Atmadipoera, et al., 2017). The availability of full annual cycle argo float CTD in situ measurement is a great opportunity for Pushidrosal to analyze it for providing tactical environment support to Indonesian Navy undersea warfare operations especially in Banda Sea.

1. DATA SOURCE AND METHODOLOGY

\subsection{Argo floats superiority as oceanography data acquisition system}

Previous studies show that Banda Sea plays a significant roles such as region of high primary productivity and pelagic fish resources, seasonal Ekman upwelling around outer Banda Arcs and active oceanatmosphere interactions which forced by monsoon winds, ENSO etc. Eventhough Banda Sea plays such an important role, adequate oceanography measurements is never been performed to collect time series data that will cover full annual cycle variations. Based on this condition a research team of IPB under coordination of Dr. Agus Atmadipoera with the colaboration and support from Ristekdikti (Indonesia), LEGOS (France) and IFREMER (France) initiated Banda Indonesian-Through Flow Dynamic Experiment (BIDE). The experiment is utilizing CTD argo float measurement that was deployed on July 29th 2017 onboard inter-islands passenger ship namely MV Kapal Perintis. The argo float was configured to perform daily CTD profiling from surface to $1000 \mathrm{~m}$ depth, scheduled for surfacing every 23:00 local time meanwhile it is drifting depends on the surrounding ocean current (Atmadipoera, et al., 2017).

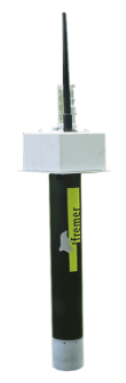

Fig. 2 Argo float BIDE picture (jcommops, 2017)

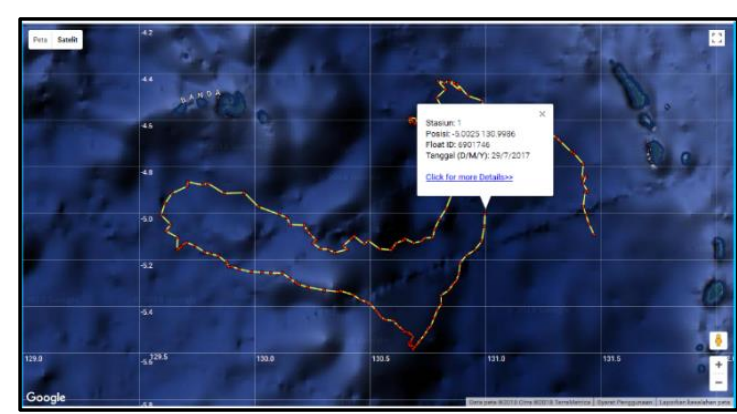

Fig. 3 Argo float BIDE trajectory as of July 2018 (Atmadipoera, 2017)

According to the research team report there are three configuration changes since the first deployment of the argo float. Configuration setting 01 was used from July to September 2017 with default configuration daily profiling and surfacing, configuration setting 02 was used from September to October 2017 with the changing of nearsurface resolution and 2-day profiling and surfacing and lastly configuration setting 03 was used from October 2017 up to now with another changing of near-surface resolution sampling while maintaing the 2-day profiling and surfacing for prolonging the battery lifetime.

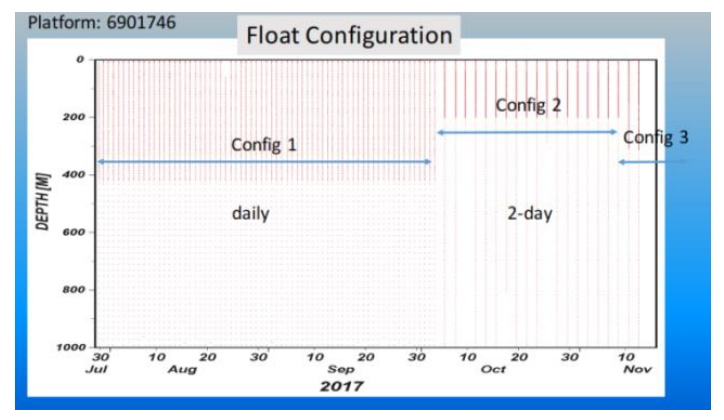

Fig. 4 Argo float BIDE configuration setting (Atmadipoera, et al., 2017) 
In order to download the argo float measurement data for full annual cycle from July 2017 up to July 2018 author accessed the jcommops web site as directed by the research team. There are several options collection data prepared by IFREMER, NRL and NOAA either in netcdf format or txt (jcommops, 2017). For the purpose of this research author chose to download data prepared by NOAA in netcdf format (NOAA, 2018).

Before BIDE actually, there was joint researh on global climate change impact utilizing 2 unit of argo floats between Agency for Marine and Fisheries Research under Indonesian Ministry of Marine Affairs and Fisheries and CSIRO Australia. This program was recorded as the first involvement of Indonesian scientist to a project utilizing argo floats as the most preferable data acquisition utility system by the International oceanography society which are relatively easy and less expensive compared to the other system (Pranowo, et al., 2003). The next two following years the acquired data measurements were already available and analyzed by the team for describing upwelling event 2003 along South Java Sea and Lesser Sunda Islands(Pranowo, et al., 2005). Another best practices of argo floats data utilization by Indonesian scientist was published just recently which was studying temperature and salinity stratification in the Eastern Indian Ocean using argo float dataset from 1999 up to 2016 with about hundreds profiles per year which is difficult to be matched by traditional data acquisition system such as CTD measurement onboard a research vessel (Purba, et al., 2018).

\subsection{Description of Data Source}

The data source was retrieved from jcommops website with filename nodc_6901746_prof.nc. According to the the metadata, the file source was taken from The Argo Global Data Assembly Center FTP server at $\mathrm{ftp}: / / \mathrm{ftp}$.ffremer.fr/ifremer/argo. Meanwhile the creator and the publisher is NOAA therefore these data were acquired from the US NOAA National Centers for Environmental Information (NCEI) on July 28th 2018 from https://www.nodc.noaa.gov/. There are three parameters that are measured by the argo float which are temperature, salinity and pressure.

Up to July 28th 2018 there are 215 stations observed that cover period of time from July 2017 to July 2018 approximately inside a box area limited by longitude $129.5^{\circ}$ $\mathrm{E}$ to $131.5^{\circ} \mathrm{E}$ and latitude $6^{\circ} \mathrm{S}$ to $4.5^{\circ} \mathrm{S}$.

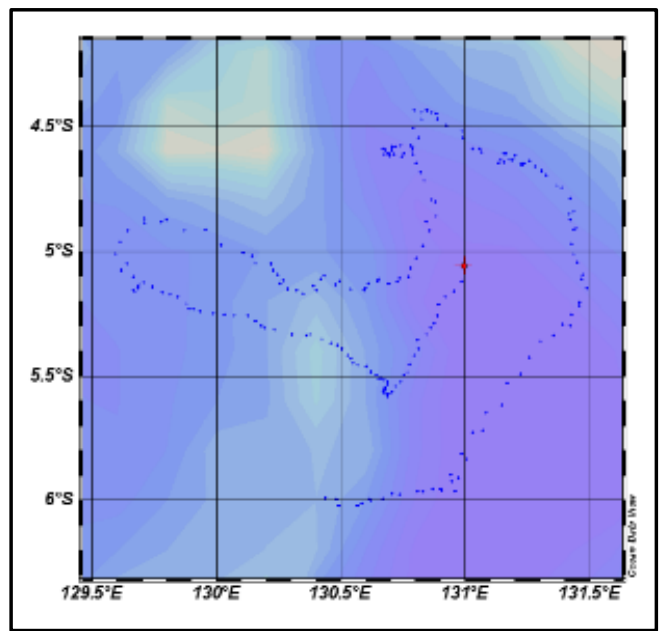

Fig. 5. Argo float BIDE distribution as of July 2018

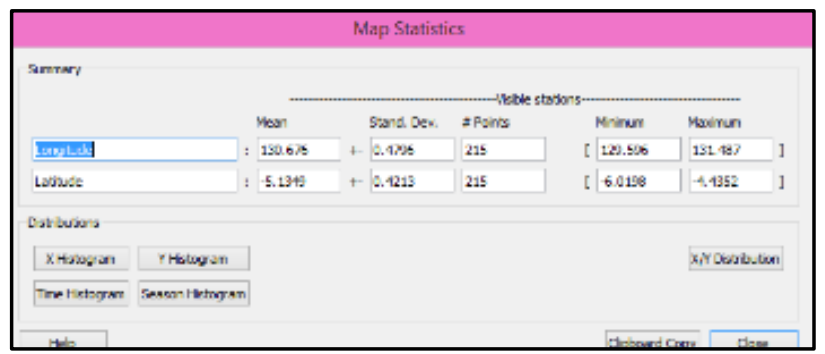

Fig. 6 Argo float BIDE statistic as of July 2018 


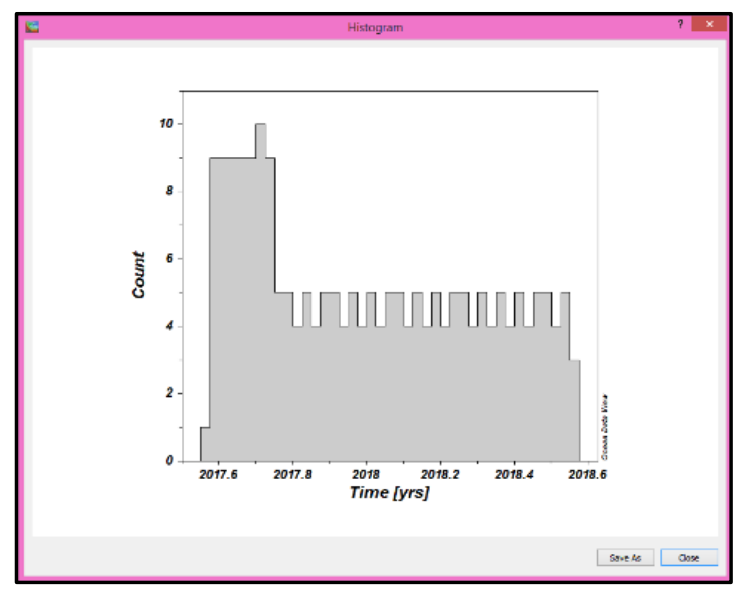

Fig. 7. Argo float BIDE time series 2017-2018

\subsection{Methodology of Research}

Several academic studies and field researh had been performed before to answer the question of how to present tactical environment support from Pushidrosal to Indonesian Navy. As early as year 2000 the first study of oceanographic layer chart concept for underwater warfare operation and exercise support was conducted by Commander Dede Yuliadi M.Sc during his Indonesian Navy staf and command school student period (Yuliadi, 2000). Since then several Indonesian Navy officers started gaining interest on this topic of research study, with some resorded topic such as layer determination and its underwater detection application (Jatmiko, 2001), underwater acoustic positioning system for the submarine (Marwoto, 2007), active sonar transmission loss (Ludfy, 2007), Tactical Ocean Data Geographic Informastion System for submarine (Taufiq, 2007), underwater acoustic propagation for submarine navigation and communication (Wahyudi, 2007), and tactical oceanography map for submarine navigation (Asryanto, 2018).

One of closely related study about sound speed propogation underwater regarding it's impact on navy operation was conducted by Tri Aji et al who analyzed the seasonal variability of thermocline, sound speed and probable shadow zone in Sunda strait published in 2017. This research was utilizing dataset from INDESO project with daily temporal resolution and $1 / 2$ degrees spatial resolution. Further explained in the publication that the study applied $0.1 \mathrm{deg} C$ gradient for the thermocline layer determinantion during four seasons data in 2014. As the results thermocline layer depth variability and it's sound speed range variability which estimated as the probable shadow zones for each four seasons and annual average was presented (Aji, et al., 2017). Another research about shadow zone and sound wave underwater propagation properties for navy sonar operation was conducted by Mario Marco Wainarisi in 2016. In his final study report he explained that this research is utilizing in situ CTD observations from The Transport, Internal Waves and Mixing in The Indonesian Throughflow Region (TIMIT) and Its Impact On Marine Ecosystem 2015 Cruise of Indonesian Marine and Fishery Ministry and CTD data from NOAA World Ocean Atlas. The research uses simulation pattern of propagation of sound waves from KRI Cakra - 401 propulsion system detected by FMS $21 / 3$ sonar with passive sonar mode. The simulation applied polynomial fitting and ray tracing methodology under matlab environment. The average pattern of sound wave propagation simulation results shows the presence of shadow zone and surface duct on each lane detected in Makassar Strait (Wainarisi, et al., 2017).

Compared to previously mentioned studies this research paralelly equivalent with Tri Aji's research methodology which will 
analyze the monthly average variations of SLD parameter with further confirmation or verification about the relation of SLD and surface duct with polynomial fitting and ray tracing methodology that applied by Marco's in his study. The use of CTD in situ observation which cover a full annual cycle make the study more realistic since generally a full annual cycle analysis, especially in Indonesia waters, can only be done from model dataset because the scarcity of in situ oceanography observations conducted until now.

Technically the downloaded dataset opened or imported into ODV software for analysis preparation. Then sample selection criteria is applied to filter the observation for only the desired month to be processed. Two derived variables of sound speed and depth from pressure are added for station plotting of temperature, salinity and sound speed. All of measured profiles (temperature, salinity and sound speed) are monthly averaged using moving average methode that is provided by ODV (Schlitzer, 2015). The averaged value of sound speed for each month then copied and saved in txt format. This monthly average value of sound speed then loaded into mathlab and investigated to get the SLD using the alghoritm of searching the depth of sound speed local maximum (matlab, 2018) that is larger than any shallower value and larger than the next deeper value, which is usually coincide or near to the MLD (Helber, et al., 2008). The monthly average sound speed profile then used to investigate the presence of surface duct using the typical hull mounted sonar source depth between 5 to $10 \mathrm{~m}$ applying the previously mentioned polynomial fitting and ray tracing methode. The confirmation will not only indicating probable shadow zone but more realistically simulate and produce a graphical representation which reasonably will give more assurance for the navy ships on the sea.

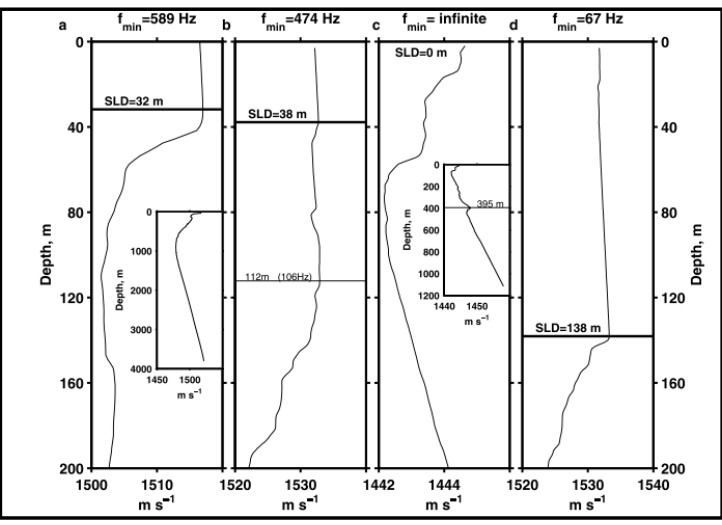

Fig. 8 Sound speed profiles versus depth for (a) standard, (b) multiple surface duct, (c) absent surface duct, and (d) deep SLD cases

(Helber, et al., 2008)

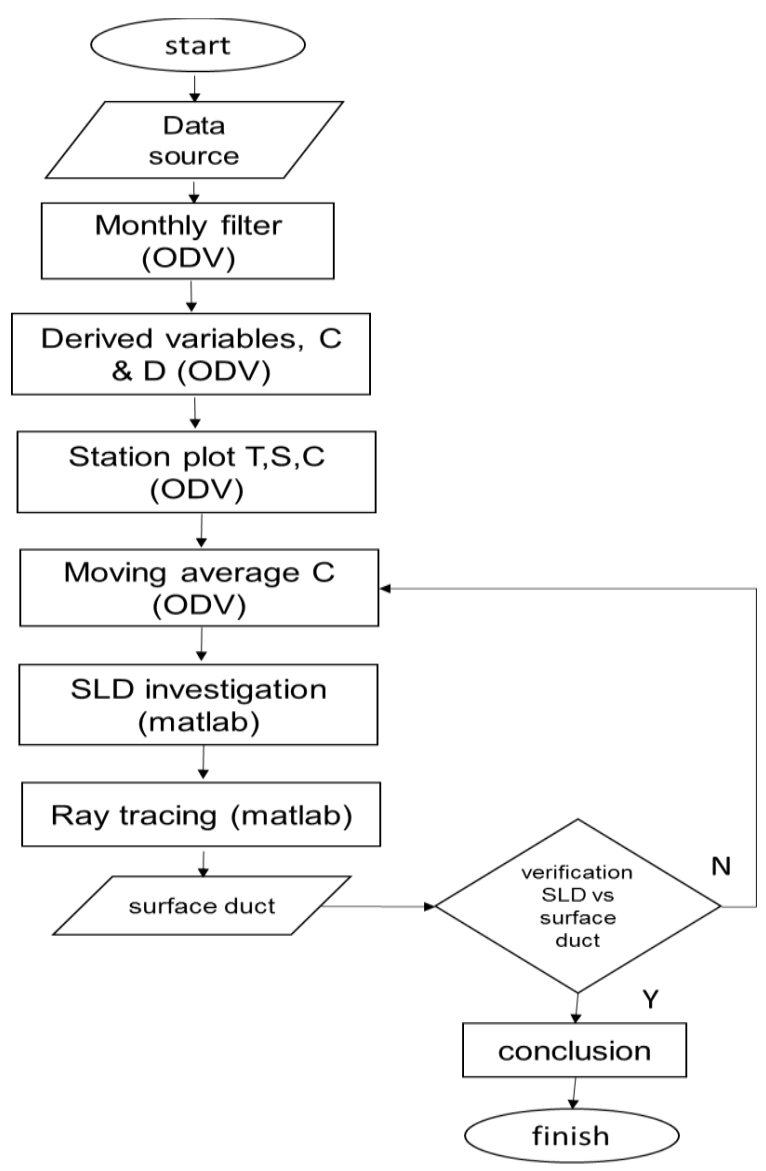

Fig. 9 Flowchart of the research 


\section{RESULT AND DISCUSSION.}

\subsection{Result.}

In this study the full annual cycle dataset is imported into ODV then two derived variables which are sound speed derived from temperature and salinity and depth derived from pressure are added to the list in order to use them for plotting and further analysis. This very first process will result 12 sound speed profiles for each 12 months which needed for the next step of SLD estimation.
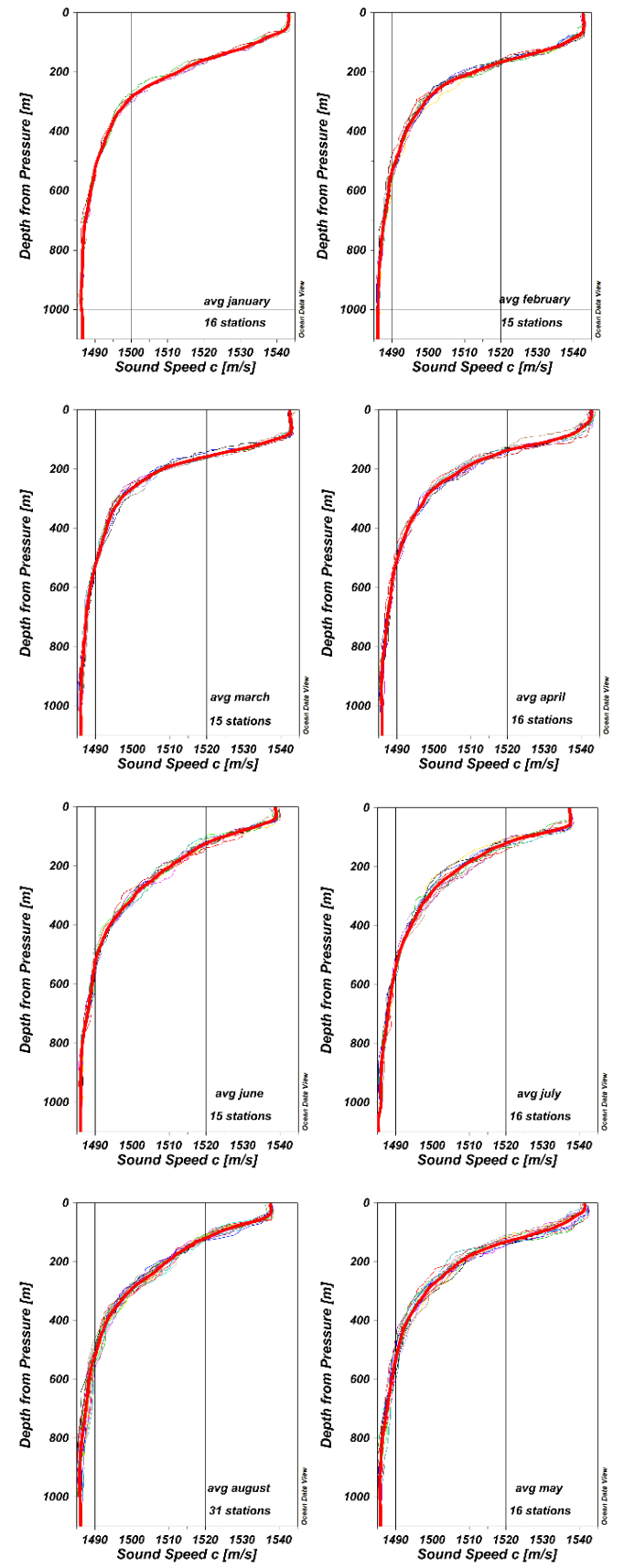
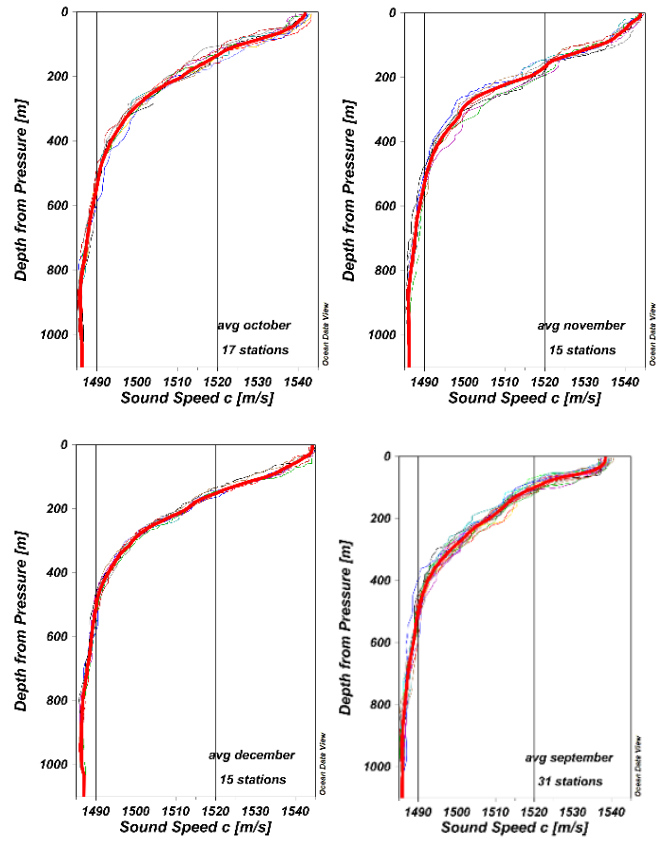

Fig. 10 Monthly average sound velocity profiles variation for the full annual cycle

The monthly average sound velocity profiles result from ODV then saved into text file to be used for SLD estimation using the searching alghoritm for local maxima in matlab software. Local maxima is a data sample that is either larger than its two neighboring samples. Additional confirmation plotting is applied for each sound velocity profiles to ensure the exact position of SLD. Once the SLD confirmed then polynomial fitting and ray tracing will be applied with the input so-called sound velocity profiles to produce the ray tracing plot which will confirm the presence of surface duct or not.

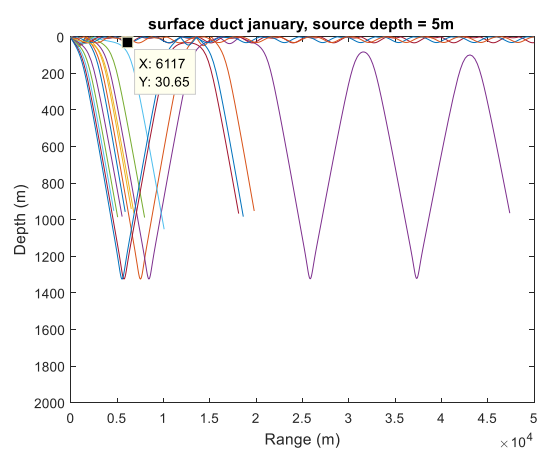




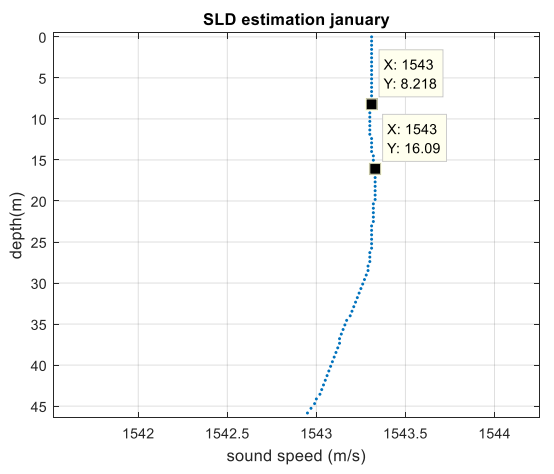

Fig. 11 SLD estimated at about $16 \mathrm{~m}$ depth, local maxima sound speed $1543.30 \mathrm{~m} / \mathrm{s}$. Surface duct simulated at about $0-30 \mathrm{~m}$ depth
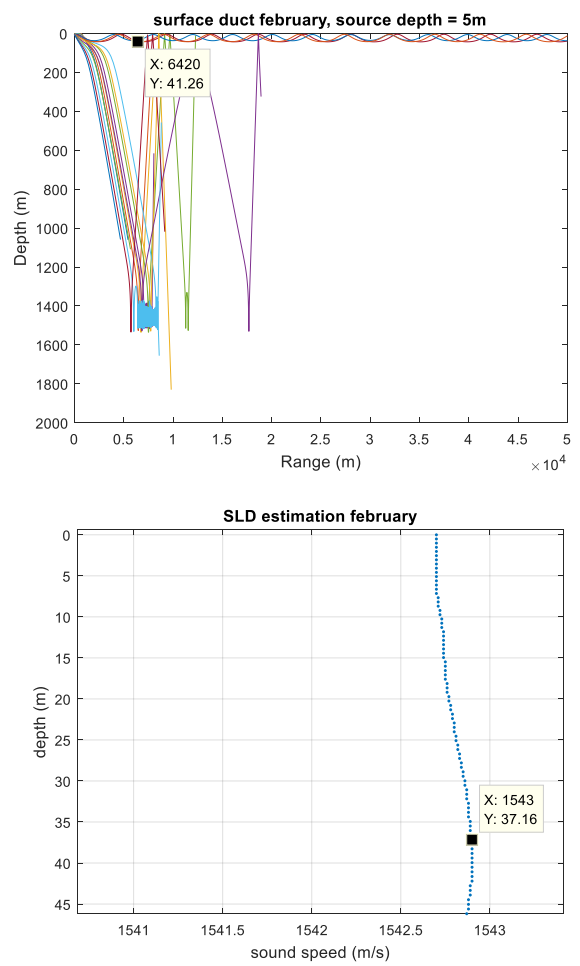

Fig. 12 SLD estimated at about $37 \mathrm{~m}$ depth, local maxima sound speed $1542.9 \mathrm{~m} / \mathrm{s}$. Surface duct simulated at about $0-41 \mathrm{~m}$ depth

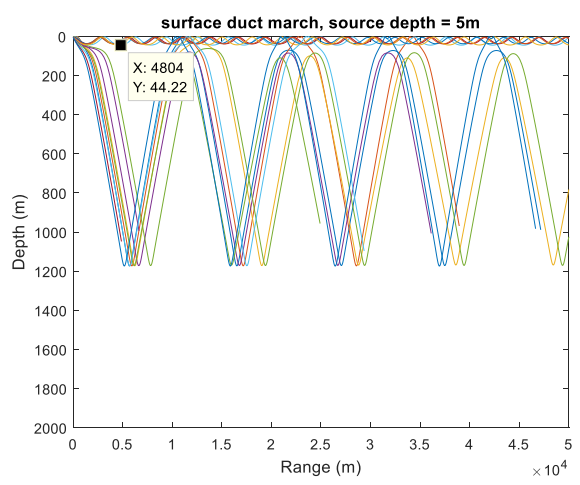

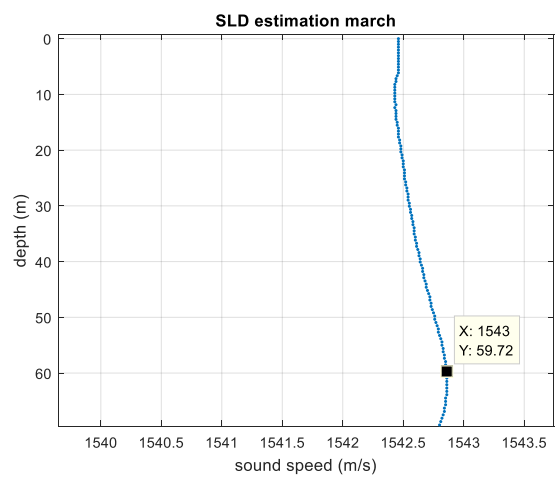

Fig. 13 SLD estimated at about $59 \mathrm{~m}$ depth, local maxima sound speed $1542.86 \mathrm{~m} / \mathrm{s}$. Surface duct simulated at about 0 - 44m depth
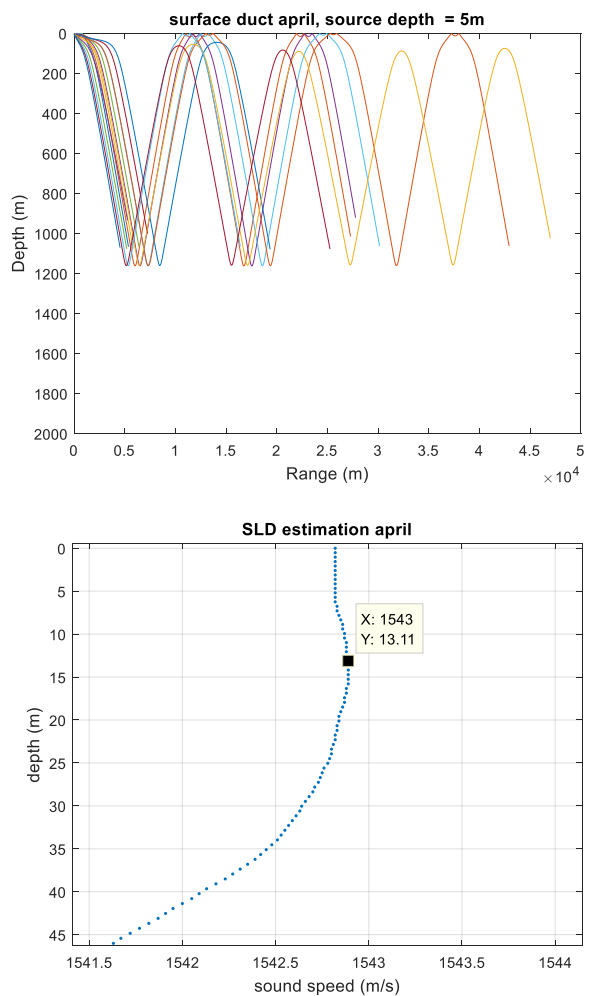

Fig. 14 SLD estimated at about $13 \mathrm{~m}$ depth, local maxima sound speed $1542.89 \mathrm{~m} / \mathrm{s}$. No surface duct simulated

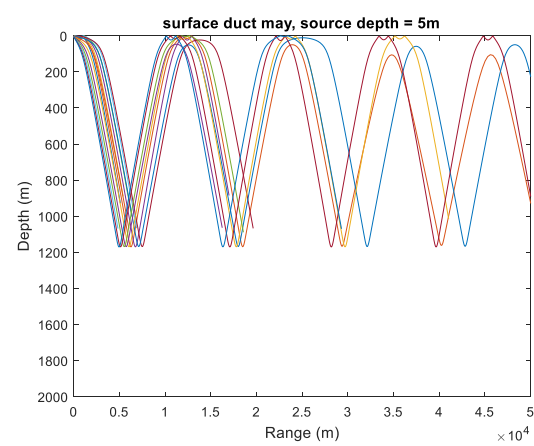




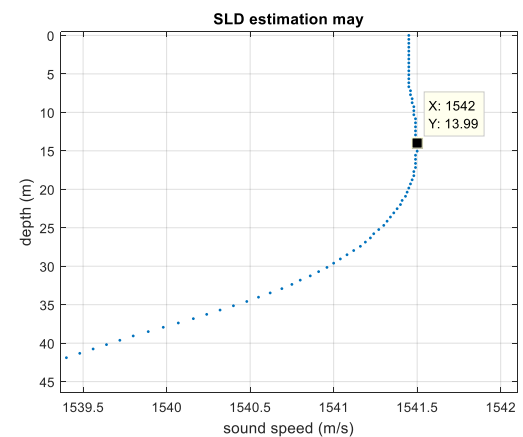

Fig. 15 SLD estimated at about $14 \mathrm{~m}$ depth, local maxima sound speed $1541.5 \mathrm{~m} / \mathrm{s}$. No surface duct simulated
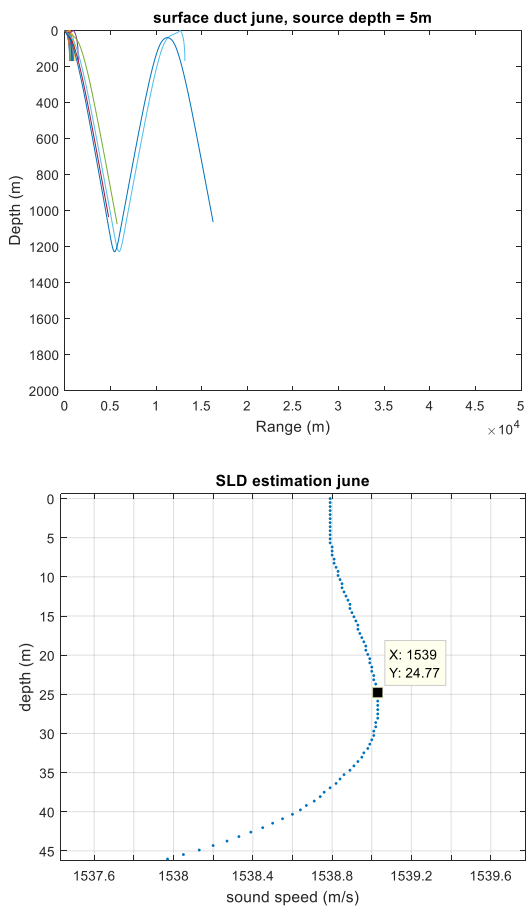

Fig. 16 SLD estimated at about $24 \mathrm{~m}$ depth, local maxima sound speed $1539.03 \mathrm{~m} / \mathrm{s}$. No surface duct simulated

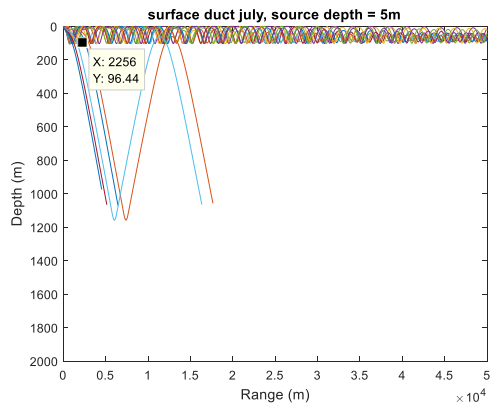

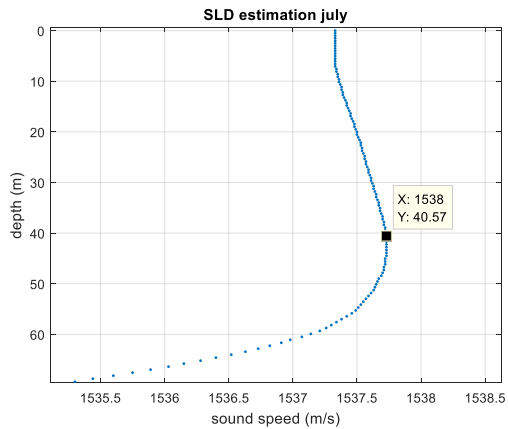

Fig. 17 SLD estimated at about 40m depth, local maxima sound speed $1537.73 \mathrm{~m} / \mathrm{s}$. surface duct simulated at about $0-96 \mathrm{~m}$ depth
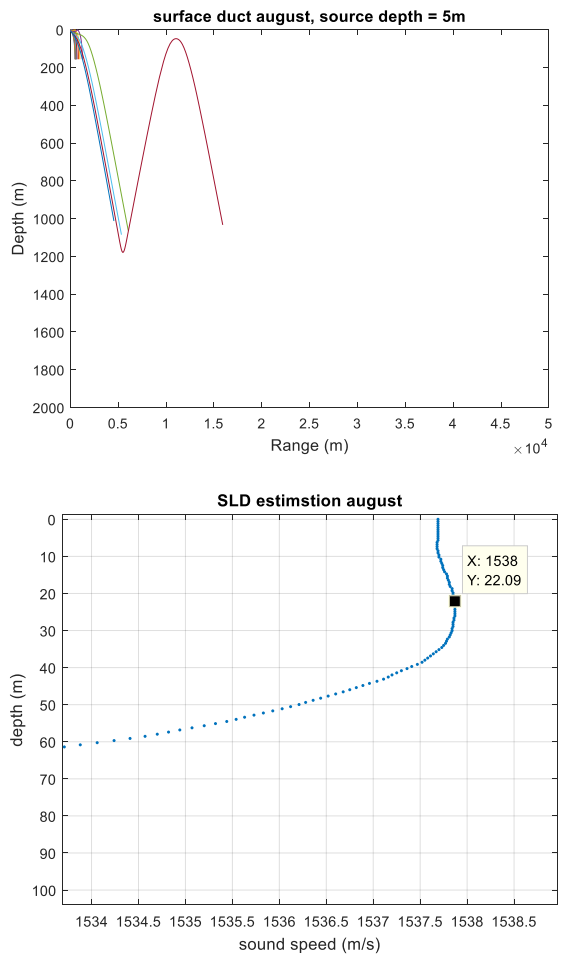

Fig. 18 SLD estimated at about $22 \mathrm{~m}$ depth, local maxima sound speed $1537.87 \mathrm{~m} / \mathrm{s}$. No surface duct simulated

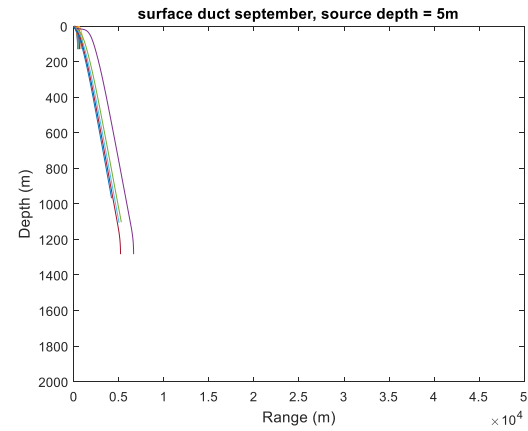




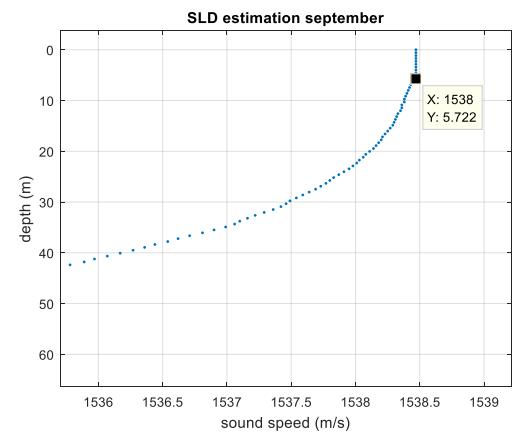

Fig. 19 SLD estimated at about $6 \mathrm{~m}$ depth, local maxima sound speed $1538.47 \mathrm{~m} / \mathrm{s}$. No surface duct simulated
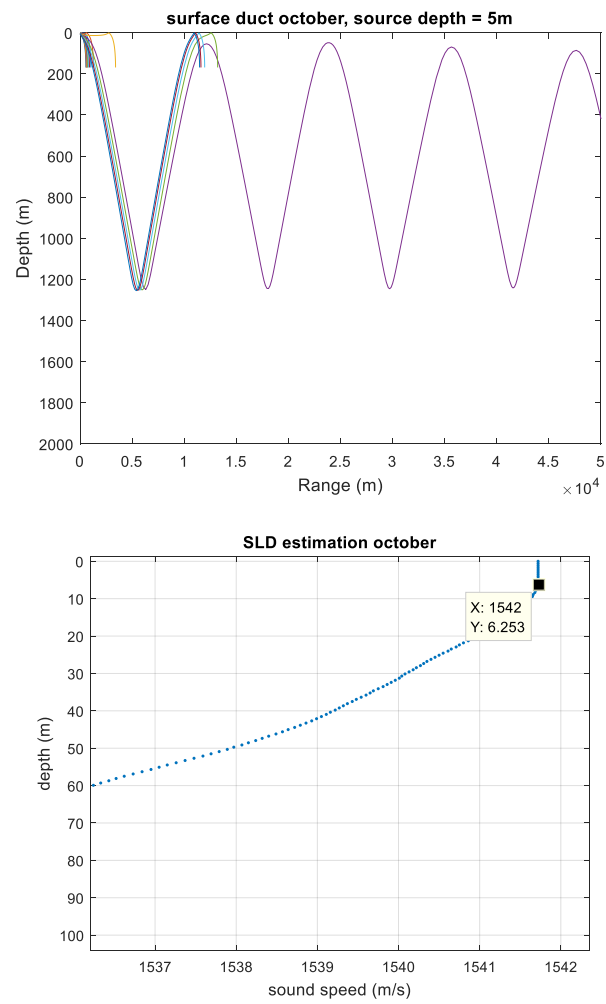

Fig. 20 SLD estimated at about $6 \mathrm{~m}$ depth, local maxima sound speed $1541.73 \mathrm{~m} / \mathrm{s}$. No surface duct simulated

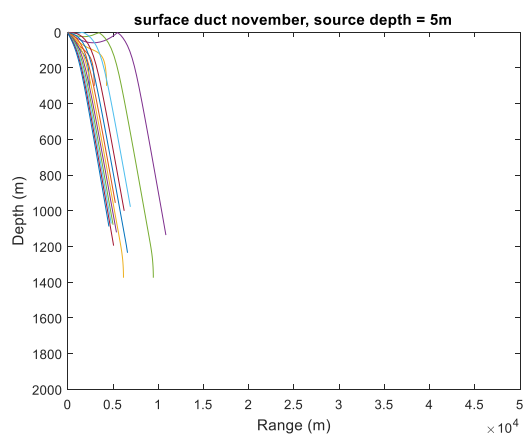

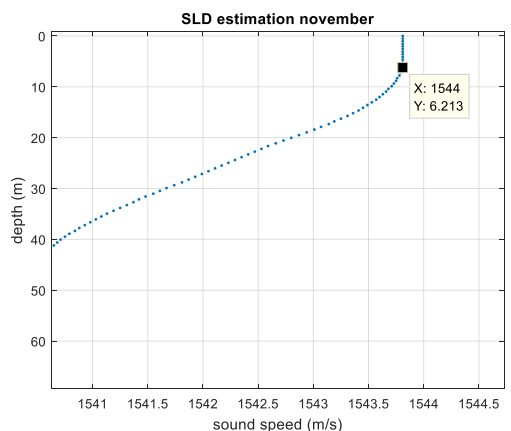

Fig. 21 SLD estimated at about $6 \mathrm{~m}$ depth, local maxima sound speed $1543.81 \mathrm{~m} / \mathrm{s}$. No surface duct simulated
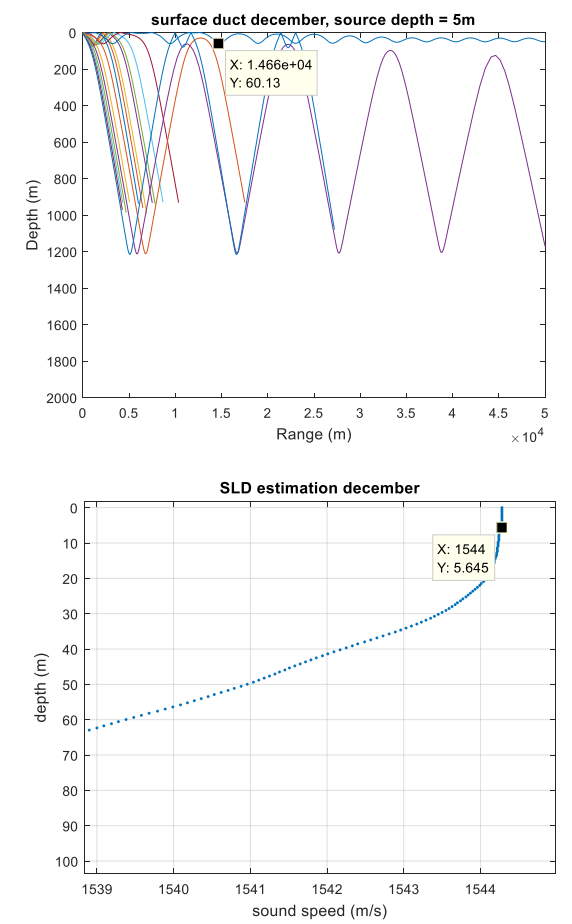

Fig. 22 SLD estimated at about $5 \mathrm{~m}$ depth, local maxima sound speed $1544.28 \mathrm{~m} / \mathrm{s}$. weak surface duct simulated at about $0-60 \mathrm{~m}$ depth

\subsection{Discussion}

The SLD estimation results monthly variations in Banda Sea based on BIDE CTD dataset. The deepest SLD estimation is in march at $59 \mathrm{~m}$ depth. The vertical distance of SLD in March is paralel with the simulated surface duct $(0-44 m)$. Actually March SLD $(59 m)$ is deeper than July SLD $(40 m)$, but the configured ray tracing simulation results shows that July surface duct vertical distance $(96 \mathrm{~m})$ is thicker than March simulated surface duct. Nevertheless, March ray tracing 
produce bottom propagation ray tracing which cover water column under the surface duct while the July ray tracing leaves water column under the surface duct empty without acoustic propagation wave. It is revealed that the depth of SLD estimate is positvely correlated with the formation of surface duct but acoustic wave propagation simulation is very complex process that is not only influenced by SLD but also other factor such as the sound velocity gradient before and after the local maxima. SLD estimation is prerequisite process to ensure the indication of the presence of surface duct, but to verify it acoustic wave propagation simulation, through ray tracing for example, should be done to further confirm how good is an active sonar performance in the current condition. The formation of surface duct is good indication that an active sonar detection range will be extended in the channel covered by surface duct. This is teoritically happen due to in a surface duct propagation the spreading loss is cylindrical spreading loss which is equal to distance ( $r$ ) meanwhile in the other propagation such as bottom bounce the spreading loss is spherical spreading loss which is equal to square distance (r2). Due to this reason under surface duct propagation acoustic wave energy will have less transmission loss which means a better probability of detection ((FAS), 2013).
Table.1 SLD estimation and surface duct simulation in Banda Sea

\begin{tabular}{|l|l|l|l|l|l|}
\hline No & Month & $\begin{array}{l}\text { SVP local } \\
\text { maxima }(\mathrm{m} / \mathrm{s})\end{array}$ & $\begin{array}{l}\text { SLD estimate } \\
(\mathrm{m})\end{array}$ & $\begin{array}{l}\text { Surface duct (source } \\
\text { depth }=5 \mathrm{~m})\end{array}$ & remarks \\
\hline 1 & January & 1543.30 & 16.09 & Simulated $(0-30 \mathrm{~m})$ & good detection range \\
\hline 2 & February & 1542.90 & 37.16 & Simulated $(0-41 \mathrm{~m})$ & good detection range \\
\hline 3 & March & 1542.86 & 59.72 & Simulated $(0-44 \mathrm{~m})$ & good detection range \\
\hline 4 & April & 1542.89 & 13.11 & Not simulated & bad detection range \\
\hline 5 & May & 1541.50 & 13.99 & Not simulated & bad detection range \\
\hline 6. & June & 1539.03 & 24.77 & Not simulated & bad detection range \\
\hline 7 & July & 1537.73 & 40.57 & Simulated $(0-96)$ & good detection range \\
\hline 8 & August & 1537.87 & 22.09 & Not simulated & bad detection range \\
\hline 9 & September & 1538.47 & 5.772 & Not simulated & bad detection range \\
\hline 10 & October & 1541.73 & 6.253 & Not simulated & bad detection range \\
\hline 11 & November & 1543.81 & 6.213 & Not simulated & bad detection range \\
\hline 12 & December & 1544.28 & 5.645 & $\begin{array}{l}\text { Simulated }(0-60 \mathrm{~m}), \\
\text { very weak }\end{array}$ & $\begin{array}{l}\text { Fairly good detection } \\
\text { range }\end{array}$ \\
\hline
\end{tabular}

\section{CONCLUSION.}

Based on the results and discussion above, the sound velocity profiles of Banda Sea varies monthly hence the SLD for each month will also vary depends on the temperature and salinity profiles which are two key variables the sound speed derived from. Single process of SLD estimation throuh the searching alghoritm of local maxima will not adequate to verify the presence of surface duct as the most favourable acoustic wave propagation for the navy ship operating active sonar to detect submarine operating in upper layer of the ocean. Polynomial fitting ray tracing process of acoustic wave propagation further ensure the relation between SLD estimates and the formation of surface duct. Generally deeper SLD will result a deeper surface duct but in the condition that there are enough sound speed gradient before and after local maxima. Therefore to more precisely predict how is acoustic wave propagates whether or not it forms surface duct, simulation should be performed utilizing the alghoritm and theory that has been well established by underwater acoustic scientists such as polynomial fitting ray tracing that is applied in this study. Actually sound speed underwater is unique even diurnally due to the influence of sun light. That is why "afternoon effect" term is very popular in anti submarine warfare. During the afternoon, the sea surface temperature reach it's maximum resulting a very strong negative sound speed gradient which degrades the sonar detection 
range heavily. The monthly variation analysis of SLD will help underwater warfare operation analyst officer in the navy to prepare and plan underwater warfare operation without the need to perform own in situ measurement which are again impractical and relatively expensive for operational budget.

\section{ACKNOWLEDGEMENT.}

The authors would like to thank to Banda Indonesia Through Flow Dynamic Experiment and NOAA (USA) from which the data source retrieved for this study, Institut Pertanian Bogor (IPB), Indonesian Ministry of Research Technology and Higher education (Ristekdikti), LEGOS (France), IFREMER (France) by whom BIDE conducted and supported. All work has been done in Marine and Coastal Data Laboratory, Marine Research Centre (Indonesian Ministry of Marine Affairs and Fisheries).

\section{BIBLIOGRAPHY.}

(FAS), F. o. A. S., 2013. Introduction of Naval Weapons Engineering : Sonar Propagation. [Online] Available at: https://fas.org/man/dod101/navy/docs/es310/SNR PROP

Aji, T., Pranowo, W. S., Harsono, G. \& Alam, T. M., 2017. Seasonal Variability of Thermocline, Sound Speed and Probable Shadow Zone in Sunda Strait, Indonesia. 13(2), pp. 111-127.

Asryanto, L., 2018. Pembangunan Purwarupa Peta Oseanografi Taktis Untuk Navigasi Kapal Selam di Selat Sunda., Jakarta: STTAL.

Atmadipoera, A., 2017. Peta Trajektori Argo float BIDE. [Online] Available at: http://itk.ipb.ac.id/BIDE/index.php?floatid=6901746

Atmadipoera, A. et al., 2017. Early insight into CTD argo float measurement in Banda Sea Indonesia, Brest, France: Institut Pertanian Bogor.
Fox, D. N. et al., 2001. The Modular Ocean Data Assimilation System. Journal of The Oceanography Society, Volume 15.

Guest, A., 2014. Direct Path Propagation. [Online] Available at: $\quad$ http://www.oc.nps.edu/bird/oc2930/acoustics/directpath.html

Helber, R. W., Barron, C. N., Carnes, M. R. \& Zingareli, R. A., 2008. Evaluating the sonic layer depth relative to the mixed layer depth. Journal of Geophysical Research, Volume 113.

Jatmiko, L. B., 2001. Menentukan Layer dan Aplikasinya untuk Deteksi Bawah Air di Selat Lombok, s.I.: STTAL.

jcommops, 2017. inspect platform 6901746 : about. [Online] Available at: http://www.jcommops.org/static/board/js/desktop/in spect/ptf/index.html?iPtfRef=6901746\#

jcommops, 2017. inspect platform 6901746 : data. [Online] Available at: http://www.jcommops.org/static/board/js/desktop/in spect/ptf/index.html?iPtfRef=6901746\#

Ludfy, L., 2007. Studi Pelemahan Pancaran Sonar Aktif Type PHS 32 di Selat Makassar, Jakarta: STTAL.

Marwoto, L. B., 2007. Studi Awal Sistem Penentuan Posisi Akustik Bawah Air Bagi Kapal Selam Kelas 209 Tipe 1300, Jakarta: STTAL.

matlab, 2018. findpeaks. [Online] Available at: https://www.mathworks.com/help/signal/ref/findpea $\underline{\mathrm{ks}}$

NOAA, 2018. nodc_6901746_prof.nc. [Online] Available at: https://www.nodc.noaa.gov/ 
Pranowo, W. S., Hendrajana, B., Burhanuddin, S. \& Supangat, A., 2003. Akuisisi Data Temperatur dan Salinitas di Samudera Hindia dengan Menggunakan Argo Floats. Jakarta, Badan Riset Kelautan dan Perikanan.

Pranowo, W. S., Philips, H. \& Wiffels, S., 2005. Upwelling Event 2003 along South Java Sea and Lesser Sunda Island. Jurnal Segara, I(3), pp. 119126.

Purba, N. P., Pranowo, W. S., Faizal, I. \& Adiwira, H., 2018. Temperature-Salinity stratification in The Eastern Indian Ocean using argo float. s.I., IOP Conf. Ser. : Earth and Environ. Sci. 162012010.

Rizanny, C. D., 2017. Merestorasi Kemampuan 'Anti Submarine Warfare' Kita. [Online] Available at: http://maritimenews.com/meretorasi-kemampuananti-submarine-warfare-kita

Schlitzer, R., 2015. Ocean Data View. [Online] Available at: $\underline{\text { http://odv.awi.de }}$

Taufiq, L. A. N., 2007. Studi Awal Pembuatan Sistem Informasi Geografis Tactical Ocean Data (SIG TOD) Untuk Operasional Kapal Selam Tipe 209/1300 (Studi Kasus di Perairan Selat Sunda), Jakarta: STTAL.
Teague, W. J., Carron, M. J. \& Hogan, P. J., 1990. A comparison between the Generalized Digital Environmental Model and Levitus Climatologies. Journal of Geophysical Research, Volume 95.

Urick, R. J., 1983. Principles of Underwater Sound. 3 penyunt. Los Altos, California: Peninsula.

Villareal, V. A., 2014. Relationship between the sonic layer depth and mixed layer depth identified from US Navy sea glider data, Monterey, California: Naval Postgraduate School.

Wahyudi, L. A., 2007. Propagasi Akustik Bawah Air Untuk Navigasi dan Komunikasi Kapal Selam TNI AL di Perairan Selat Makassar, Jakarta: STTAL.

Wainarisi, M. M., Kusumawardani, A. T. D. \& Brodjonegoro, I., 2017. Studi Lapisan Termoklin Untuk Menentukan Pola Perambatan Gelombang Suara Di Selat Makasar, Jakarta: STTAL.

Yuliadi, C. D., 2000. Konsep Penyediaan Peta Layer dalam Mendukung Operasi dan Latihan Peperangan Bawah Air, Jakarta: Seskoal. 